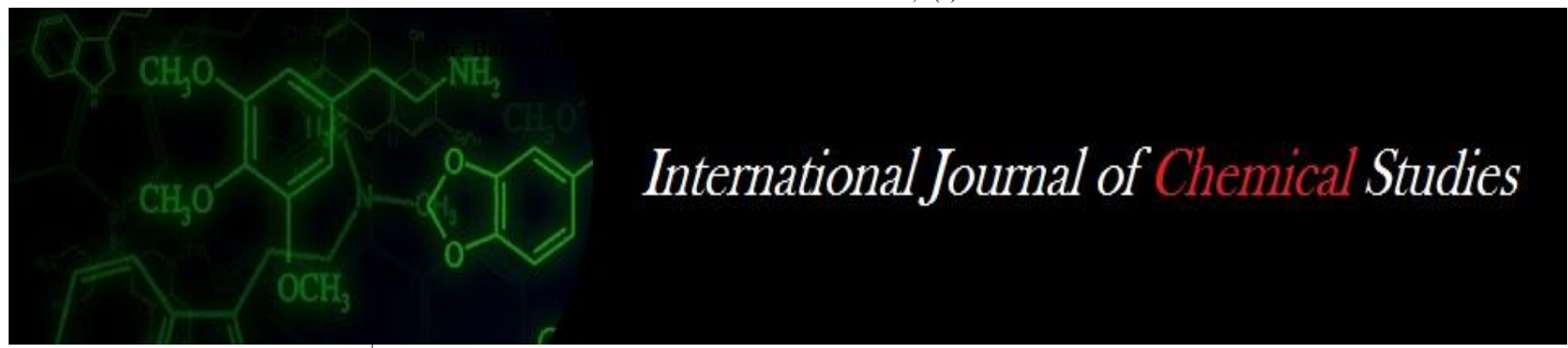

P-ISSN: 2349-8528

E-ISSN: 2321-4902

www.chemijournal.com

IJCS 2020; 8(4): 3438-3441

(C) 2020 IJCS

Received: 19-05-2020

Accepted: 21-06-2020

Ashutosh Singh

Assistant Professor-cum-Junior

Scientist, Mandan Bharti

Agriculture College, Agwanpur,

Saharsa, Bihar, India

Amit Kumar Pandey

Assistant Professor-cum-Junior

Scientist, Mandan Bharti

Agriculture College, Agwanpur,

Saharsa, Bihar, India

Umesh Singh

Associate Dean-cum-Principal,

Mandan Bharti Agriculture

College, Agwanpur, Saharsa,

Bihar, India
Corresponding Author: Amit Kumar Pandey

Assistant Professor-cum-Junior

Scientist, Mandan Bharti

Agriculture College, Agwanpur,

Saharsa, Bihar, India

\section{Effect of integrated nutrient management practices on soil chemical properties: A review}

\author{
Ashutosh Singh, Amit Kumar Pandey and Umesh Singh
}

DOI: $\underline{\text { https://doi.org/10.22271/chemi.2020.v8.i4aq.10186 }}$

\begin{abstract}
A long term imbalanced use of fertilizers is adversely affecting the sustainability of agricultural production eventually causing environmental pollution. The major issue for the sustainable agricultural production will be management of soil organic carbon and rational use of organic inputs as integrated plant resource management. It play a vital role in improving stocks of plant nutrient in soil by increasing the efficiency of plant nutrients, thus limiting losses to the environment. It optimize the function of the soil biosphere and ultimately sustaining the physical, chemical and biological function of soil. This paper has reviewed the research work carried out by various scientist on impact of integrated nutrient management on different soil chemical properties in India and abroad.
\end{abstract}

Keywords: Effect, INM, Soil, pH, EC, CEC

\section{Introduction}

Soil pH

Soil $\mathrm{pH}$, a function of parent materials, weathering time, vegetation and climate is considered as one of the dominant chemical indicators of soil characteristics, identifying trends in change for a range of soil biological and chemical function, nutrient availability and biological activities. Application of inorganic fertilizers and organic manures has been reported to affect soil pH. Chaudhary et al., $1981^{[11]}$ reported that the continuous application of FYM decreased the soil $\mathrm{pH}$, as farm yard manure released different organic acids during the decomposition process. Kumar et al., $2006^{[17]}$ evaluated the effect of integrated nutrient supply on physicochemical properties of soil and reported that a decrease in the soil $\mathrm{pH}$ was observed with organic manure. The lowest soil $\mathrm{pH}$ of 7.3 against initial value of 7.6 was recorded with $100 \%$ $\mathrm{NPK}+$ vermicompost. Acid produced during the decomposition of organic matter and released by the microbes are responsible for the reduction in soil $\mathrm{pH}$.

The initial soil had a $\mathrm{pH}$ of 8.5 and at the end of $25^{\text {th }}$ crop cycle the $\mathrm{pH}$ in various treatments was ranging from 8.12 to 8.18 . This important indicator was not influenced significantly by the application of fertilizers continuously or due to integrated nutrient management compared to control. The acidifying effect of $\mathrm{N}$ fertilizers is nullified with the improvement in buffering capacity of soil under integrated use of organic manure (Sridevi and Ramana, 2016) ${ }^{[35]}$. pH of surface and sub-surface soils were not affected significantly by long term application of nutrients. It is also evident that $\mathrm{pH}$ of surface and sub-surface soil were slightly increased in treatments of inorganic nutrient application alone while slight decrease in soil $\mathrm{pH}$ was recorded in the treatment received FYM along with inorganic nutrients (Chouhan et al., 2017) [13]. Dwivedi et al., 2007 also reported that soil pH remained almost unchanged manure, might be due to solubilising effect of FYM.

The soil $\mathrm{pH}$ at $0-15 \mathrm{~cm}$ depth varied significantly after twenty-ninth cycle of rice crop. The lowest $\mathrm{pH}$ in the surface soil was registered under control while the highest $\mathrm{pH}$ to the tune of 8.19 was recorded due to NPK + FYM. There was no remarkable variation in soil $\mathrm{pH}$ due to various treatments of nutrient management through chemical fertilizers alone or in combination with FYM (Bhatt et al., 2017) ${ }^{[8]}$. The results of continuous cropping and fertilization after 32 years, revealed non-significant impact of various treatments on soil $\mathrm{pH}$. Soil $\mathrm{pH}$ was slight high in treatments where integrated use of fertilizers and manures was made (Bhatt et al., 2019) ${ }^{[9]}$. This marginal increase in soil $\mathrm{pH}$ in integrated treatments might be due to the moderating effect of organics over the year as it decreases the activity of 
exchangeable $\mathrm{Al}^{3+}$ ions in soil solution due to chelating effect of organic molecules (Prasad et al., 2016) ${ }^{[27]}$. According to Sharma et al. (1988) ${ }^{[33]}$ soil pH was maintained or declined with integrated nutrient management treatments effects 31 years compared to initial values.

Application of FYM, rice straw and green manure along with inorganic fertilizers decreased soil $\mathrm{pH}$ as compared to the fertilizers alone in rice-wheat cropping system (Kumar et al., 2012) ${ }^{[18]}$. Selvi et al., $2005^{[31]}$ reported that application of chemical fertilizers for 32 years significantly reduced soil $\mathrm{pH}$ while application of organic manure improved soil $\mathrm{pH}$. The increase in soil $\mathrm{pH}$ might be due to moderating effect of organic manures as it decreases the activity exchangeable $\mathrm{Al}^{3+}$ ions in the solution due to chelation effect of organic molecules. The soil $\mathrm{pH}$ in the treatment receiving recommended dose of inorganic fertilizers was 7.24 which decreased to 7.08 and 7.04 with the addition of FYM and vermicompost. This was ascribed to the acidifying effect of organic acids produced during the course of decomposition of organic amendments (Srikantha et al., 2000) ${ }^{[36]}$. Parvathi et al., $2013^{[26]}$ studies the long term effect of manure and fertilizers on physical and chemical properties of Alfisols and observed that soil $\mathrm{pH}$ was the highest in FYM treated plots (5.51) and the lowest in NPK + lime plots (5.21) lower value of $\mathrm{pH}$ was recorded in the treatment where recommended dose of NPK along with 8 tonnes/ha organic manure was applied and this might be due to production of $\mathrm{H}+$ ions and subsequently release of $\mathrm{H}+$ in the solution resulting from heavy application of organic manure to the soil (Sur et al., 2010). More (1994) ${ }^{[37]}$ had also reported that the application of farm wastes and organic manures reduced the $\mathrm{pH}$ of the

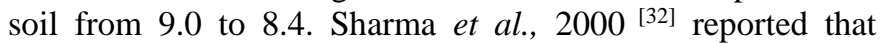
integrated application of FYM and chemical fertilizers resulted in slight reduction in soil $\mathrm{pH}$ in all the treatments.

\section{Electrical conductivity}

Soil electrical conductivity a measure of salt concentration indicates trend in salinity, nutrient recycling and biological activities along with $\mathrm{pH}$. It can act as surrogate measure of soil structured declined, especially in sodic soil. The electrical conductivity of the soil decreased with the application of FYM. The decrease in electrical conductivity might be due to the release of different organic acid during decomposition process which solubilised the salt and that leached down through irrigation water (Chaudhary et al., 1981) ${ }^{[11]}$.

Bharadwaj and Omanwar (1992) ${ }^{[5]}$ studies long term effect of continuous rotational cropping and fertilization on soil properties and reported that electrical conductivity was not affected by any of the treatments, while Santhy et al., 1999 [30] reported that a slight increase in salt content was observed with the application of 100 per cent NPK + FYM and a considerable increase with the application of inorganic alone at different levels and at various combinations. The electrical conductivity of soil was evaluated after the harvest of rice as well as wheat crop by Bharambe et al. (2004) ${ }^{[6]}$ which revealed that there was no significant change in electrical conductivity of soil with the application of various fertilizer combinations with and without FYM. Kumar et al. (2006) ${ }^{[17]}$ reported that electrical conductivity of soil decreased with the application of organic manure. The electrical conductivity of surface and sub-surface soil after harvest of soybean and wheat crop was not affected significantly by the treatments of long term application of integrated nutrients. The value of electrical conductivity did not show remarkable alteration and this may be attributed to low residual effect of applied input and high buffering capacity of soil (Chouhan et al., 2017) ${ }^{[13]}$. Lal Bahadur et al., $2012^{[19]}$ also reported that no marked influence of continuous use of inorganic fertilizers alone or in combination of FYM on electrical conductivity of soil and thus may be due to buffering capacity of soil.

The lowest electrical conductivity was recorded in control $\left(0.27 \mathrm{dSm}^{-1}\right)$ while the highest electrical conductivity $(0.33$ $\mathrm{dSm}^{-1}$ ) was recorded with the treatment NPK + FYM in surface soil. Addition of NPK fertilizers increases accumulation of salts concentration in soil which contribute to increased electrical conductivity (Bhatt et al., 2017) ${ }^{[8]}$. The highest value of electrical conductivity was recorded $(0.32$ $\mathrm{dSm}^{-1}$ ) where $100 \%$ NPK was applied followed by treatment where $25 \% \mathrm{~N}$ applied through FYM with $75 \% \mathrm{NPK}$, while the lowest value of electrical conductivity was found $(0.26$ $\mathrm{dSm}^{-1}$ ) in the control treatment. This might be due to the effect of inorganic fertilizers on electrical conductivity which was increased with increase in recommended inorganic fertilizers levels (Bhatt et al., 2019) ${ }^{[9]}$. Aziz et al., $2012^{[1]}$ also found similar results while studying effect of integrated nutrient management on soil physical properties using soybean as indicator crop under temperate condition. This might be due to release of electrolysis upon the decomposition of applied manure and fertilizers. A study in a permanent manorial trail on aridisols showed an increase in soil electrical conductivity value from $0.67 \mathrm{dSm}^{-1}$ to 0.80 $\mathrm{dSm}^{-1}$ due to the continuous application of fertilizers for over 30 years. The increase in the electrical conductivity of the soil with continuous application of fertilizers was due to addition of salts through fertilizers and solubilization of native minerals due to reduction in $\mathrm{pH}$ (Hemlatha et al., 2013) ${ }^{[16]}$. Kumar et al., $2012^{[18]}$ reported that application of FYM, rice straw and green manure along with inorganic fertilizer decreased soluble salt concentration compared to the fertilizers alone in rice-wheat cropping system. The application of FYM @ $10 \mathrm{tha}^{-1}$ to groundnut and $15 \mathrm{t} \mathrm{ha}^{-1}$ to wheat significantly reduced electrical conductivity over control. Application of FYM and fertilizers reduced the electrical conductivity of soil. This could be attributed to increased of cation exchange capacity by addition of FYM and fertilizers (Rajani et al., 2019) ${ }^{[28]}$.

\section{Cation exchange capacity}

Cation exchange capacity is a measure of how many cations can be retained on soil particles surface. It is the total capacity of a soil to hold exchangeable cations. It is an inherent soil characteristic and is difficult to alter significantly. Cation exchange capacity of soil increased in soil treated with $100 \%$ vermicompost followed by $50 \%$ vermicompost supplemented with 50\% NPK when compared to control (Manivannam et al., 2009) ${ }^{[22]}$. Bharti and Sharma (2017) ${ }^{[7]}$ reported that continuous use of chemical fertilizers and amendments reduced the CEC values in almost all the treatment except that of $100 \%$ NPK + FYM where the initial status was almost maintained. Report of the long term effect of continuous use of chemical fertilizers and manures reported that after 16 cropping cycle cation exchange capacity of soil increased in all the treatments over the initial status of soil (Sharma et al., 2014) ${ }^{[34]}$. Chauhan et al., $2017^{[12]}$ reported that highest value of CEC was recorded in the treatment $100 \%$ NPK with FYM and lowest in control.

Cation exchange capacity was recorded maximum in the treatment receiving 5 tonnes of farm yard manures + nitrogen fixer $-\mathrm{B}+$ half dose of nitrogen + phosphate solubilizers + 
half dose of $\mathrm{P}_{2} \mathrm{O}_{5}$. The values of CEC were significantly higher in integrated treatments than organic treated (Datt et al., 2013) ${ }^{[14]}$. The CEC value of soil was comparatively high in $100 \%$ NPK + FYM treated plots which might be due to the higher organic colloids in these plots. The increase in CEC with the addition of FYM can be attributed to the increase in root biomass and crop residue production and then incorporation in soil (Meena et al., 2017) ${ }^{[23]}$. Bellaki et al., $1998^{[4]}$ stated that combined application of organic and inorganic sources of nutrients resulted significant increase in CEC over control. The CEC of the soil was found to be significantly increased by the application of higher rate of FYM and the best treatment was application of 7.5 tonn FYM ha $^{-1}$ with the half dose of $\mathrm{N}$ and $\mathrm{P}$ fertilizers (Rajshree et al., 1995) ${ }^{[29]}$. Pandey and Shukla (2006) [25] indicated that application of vermicompost charged effective cation exchange capacity of the soil due to change of negative of the soil colloids.

The effective cation exchange capacity of the soil was significantly affected by all treatments except the chemical $\mathrm{P}$ fertilizers when applied at the rate of 40 and $60 \mathrm{~kg} \mathrm{ha}^{-1}$. The increase was due to improved soil condition by vermicompost and lime and increase of negative charges on the surface of the soil colloids (Bekela et al., 2018) [3]. Mahmoud and Ibrahim (2012) [21] reported that CEC was increased significantly with the application of vermicompost alone and it's in combination with water treated residue. The lowest CEC was found in non-treated control and the higher CEC was found in $150 \%$ NPK treatments. The highest CEC due to NPK fertilizers application compared to FYM might be due to more aromatic nature of organic matter produced under NPK fertilizer treatment compared to FYM (Brar et al., 2015) ${ }^{[10]}$.

Basumatary and Talukdar (1998) ${ }^{[2]}$ reported that continuous combined application of chemical fertilizer and organic manure increased the cation exchange capacity of soil over the initial value, where as soil fertility deterioration was observed under chemical fertilizers. Incorporation of crop residue and inorganic fertilizers showed significant increase in cation exchange capacity over the initial value. The increase in CEC was due to improvement in organic carbon content of the soil (Sharma et al., 2000) ${ }^{[32]}$. Laxminarayana (2001) ${ }^{[20]}$ reported that higher CEC of the soil due to integrated use of organic and inorganic fertilizer in soybeanwheat cropping system mainly because of increased organic carbon content in soil. Long term application of inorganic nutrient along with organic manure significantly increased the cation exchange capacity of soil. Higher CEC in the treatments of long term application of integrated nutrient along with FYM was might be due to higher organic carbon under these treatments (Chauhan et al., 2017) ${ }^{[12]}$. Rajani et al., $2019^{[28]}$ reported a significant increase in cation exchange capacity in the treatment receiving FYM @ $10 \mathrm{t} \mathrm{ha}^{-1}$ with $50 \%$ NPK, 50\% NPK with rhizobium + PSM to groundnut and $100 \%$ NPK to wheat as compared to rest of the treatment.

\section{References}

1. Aziz MA, Amees TA, Mahdi SS, Ali T. Effect of integrated nutrient management on soil physical properties using soybean as indicator crop under temperate condition. International Journal of Current Research. 2012; 4(1):203-207.

2. Basumatary A, Talukdar MC. Long-term effect of integrated nutrient supply system on soil properties in an inceptisol of Assam. Oryza. 1998; 35(1):43-46.
3. Bekela A, Kibert K, Badadi B, Halla M, Balemi T. Effect of lime, vermicompost and chemical $\mathrm{P}$ fertilizer on selected properties of acid soils of Ebantu district, Western Highlards of Ethopia. Applied and Environmental Soil Science, Article I D 8178305, 2018, 13.

4. Bellaki MA, Badanur VP, Setty RA. Effect of long-term integrated nutrient management on some important properties of a vertisol. Journal of the Indian Society of Soil Science. 1998; 46(2):176-180.

5. Bharadwaj V, Omanwar PK. Impact of long-term fertilizing treatments on bulk density, water contents and microbial population of soil. Journal of the Indian Society of Soil Science. 1992; 40:553-555.

6. Bharambe PR, Patil VV, Shelke DK, Oza SR, Sondge VD. Response of Rabi groundnut to phosphorus levels under different land layouts and moisture regimes grown on vertisol. Journal of the Indian Society of Soil Science. 2004; 52(3):262-265.

7. Bharti B, Sharma RP. Long term effect of integrated nutrient management in a Typic Hapludalfs under maizewheat cropping. International Journal of Environmental and Agricultural Research. 2017; 3(6):43-48.

8. Bhatt MK, Labanya R, Joshi HC, Pareek N, Chandra R, Raverkar KP. Long-term effects of inorganic fertilizers and FYM on soil chemical properties and yield of wheat under rice-wheat cropping system. ENVIS Himalayan Bulletin. 2017; 25:28-35.

9. Bhatt M, Singh AP, Singh V, Kala DC, Kumar V. Long term effect of organic and inorganic fertilizers on soil physico-chemical fertilizers of a silty clay loam soil under rice-wheat cropping system in Tarai region of Uttarakhand. Journal of Pharmacognosy and Phytochemistry. 2019; 8(1):2113-2118.

10. Brar BS, Singh J, Singh G, Kaur G. Effect of long term application of inorganic and organic fertilizers on soil organic carbon and physical properties in maize wheat rotation. Agronomy. 2015; 5:220-231.

11. Chaudhary ML, Singh JP, Narwal RP. Effect of long term application of $\mathrm{P}, \mathrm{K}$ and FYM on soil chemical properties. Journal of the Indian Society of Soil Science. 1981; 29:81-85.

12. Chauhan B, Rai HK, Suryawanshi A. Assessment of chemical properties of a vertisol under long term fertilizers experiment in soybean-wheat cropping system. International Journal of Chemical Studies. 2017; 5(6):2107-2111.

13. Chouhan B, Rai HK, Suryawanshi A. Assessment of chemical properties of a Vertisol under long-term fertilizer experiment in soybean-wheat cropping system. International Journal of Chemical Studies. 2017; 5(6):2107-2111.

14. Datt N, Dubey YP, Chaudhary Rohina. Studies on impact of organic, inorganic and integrated use of nutrients on symbiotic parameters, yield, quality of French bean vis-avis soil properties of an acid alfisol. African Journal of Agricultural Research. 2013; 8(22):2645-2654.

15. Dwivedi AK, Singh M, Kauraw DL, Wanjari RH, Chauhan SS. Research bulletin on impact of fertilizer and manure use for three decades on crop productivity and sustainability and soil quality under Soybean-Wheat system on a Vertisol in Central India. IISS, 2007, 224235.

16. Hemlatha S, Radhika K, Maragathan S, Katharin SP. Influence of long term fertilization on soil fertility. 
Journal of Agriculture and Allied Sciences. 2013; 2(3):30-36.

17. Kumar R, Pal S, Singh NB. Yield, uptake and soil fertility in rice-wheat cropping system under integrated nutrient management. Annals of Plant and soil research. 2006; 8(1):39-41.

18. Kumar S, Dahiya Rita, Kumar P, Jhorar BS. Long - term effect of organic materials and fertilizers on soil properties in pearl millet-wheat cropping system. Indian Journal of Agricultural Research. 2012; 46(2):161-166.

19. Lal Bahadur, Tiwari DD, Mishra J, Gupta BR. Effect of integrated nutrient management on yield, microbial population and changes in soil properties under ricewheat cropping system in sodic soil. Journal of the Indian Society of Soil Science. 2012; 60(4):326-329.

20. Laxminarayana K. Effect of nitrogen, phosphorus and potassium on yield performance of maize under mid hills of Mizoram. Indian Journal of Hill Farming. 2001; 14(1):132-135.

21. Mahmoud EK, Ibrahim MM. Effect of vermicompost and its mixture with water treatment residues on soil chemical properties and barley growth. Journal of Soil Science and Plant Nutrition. 2012; 12(3):431-440.

22. Manivannam S, Balamurugan $M$, Parthasarthi $K$, Gunashkaram G, Rangnathan LS. Effect of vermicompost on soil fertility and crop productivity beans. Journal of Environment Biology. 2009; 30(2):275281.

23. Meena HM, Sharma RP, Sankhyan NK, Sepehya AC. Effect of continuous application of fertilizers, FYM and lime on soil fertility and productivity of the maize-wheat system in an acid alfisols. Communication in Soil Science and Plant Analysis. 2017; 48(13):1552-1563.

24. More SD. Effect of farm wastes and organic manures on soil properties, nutrient availability and yield of ricewheat grown on sodic vertisol. Journal of the Indian Society of Soil Science. 1994; 42(2):253-260.

25. Pandey C, Shukla S. Effect of composted yard waste on water nutrient in sandy soil. Compost Science and Utilization. 2006; 14(4):252-259.

26. Parvathi E, Venkaiah K, Munaswamy V, Naidu MV. Long term effect of manure and fertilizers on the physical and chemical properties of an alfisols under semi-arid rainfed conditions. International Journal of Agricultural Science. 2013; 3:500-505.

27. Prasad J, Karmakar S, Kumar R, Mishra B. Influence of integrated nutrient management on yield and soil properties in maize-wheat cropping system in an alfisol of Jharkhand. Journal of the Indian Society of Soil Science. 2016; 58(2):200-204.

28. Rajani AV, Wediya SP, Jadeja AS, Hirpara DV. Long term effect of balanced nutrients managements on dynamics of important chemical properties of a calcareous soil. Journal of Pharmacognosy and Phytochemistry. 2019; 8(5):238-241.

29. Rajshree MW, Maya MR, Swati VW, Bharti SB. Effect of long term fertilizer application of N, P, Zn and FYM on soil properties of vertisol, yield, protein and oil content of soybean. Journal of Soil Crops. 1995; 15(1):155-159.

30. Santhy P, Velusamy MS, Muragappan V, Selvi D. Effect of inorganic fertilizers and fertilizer-manure combination on soil physico-chemical properties and dynamics of microbial biomass in an Inceptisol. Journal of the Indian Society of Soil Science. 1999; 47:479-482.
31. Selvi D, Santhy P, Dhakshinamoorthy M. Effect of inorganics alone and in combination with farm yard manure on physical properties and productivity of Vertic Haplustepts under long term fertilization. Journal of the Indian Society of Soil Science. 2005; 53:302-307.

32. Sharma MP, Bali SV, Gupta DK. Crop yield and properties of inceptisol as influenced by residue management under rice - wheat cropping sequence. Journal of the Indian Society of Soil Science. 2000; 48(3):506-509.

33. Sharma RP, Roy PK, Jha CB. Production potential and economics of rice-wheat sequence as influenced by organic and inorganic fertilizer. Annals of Agricultural Research. 1988; 9:280-283.

34. Sharma U, Paliyal SS, Sharma SP, Sharma GD. Effects of continuous use of chemical fertilizers and manure on soil fertility and productivity of maize-wheat under rainfed conditions of the western Himalayas. Communication in Soil Science and Plant Analysis. 2014; 45(20):2647-2659.

35. Sridevi S, Ramana MV. Impact of long term integrated nutrient management on soil properties in rice-rice cropping system. Green Farming. 2016; 4(5):1106-1110.

36. Srikantha K, Srinivashamurthy CA, Ramakrishna VR. Direct and residual effect of enriched compost, FYM, vermicompost and fertilizers on alfisols. Journal of the Indian Society of Soil Science. 2000; 54:30-37.

37. Sur P, Mondal M, Das DK. Effect of integrated nutrient on soil fertility and organic carbon in cabbage growing soil. Indian Journal of Agricultural Sciences. 2010; 80(8):695-698. 